\title{
EVALUATION OF GREEN MARKETING PERFORMANCE: A METHODOLOGICAL PERSPECTIVE
}

\author{
Ilona SKACKAUSKIENE ${ }^{1}$, Neringa VILKAITE-VAITONE ${ }^{2}$ \\ 1,2 Vilnius Gediminas Technical University, Vilnius, Lithuania \\ Corresponding author e-mail: neringa.vilkaite-vaitone@vgtu.lt
}

\begin{abstract}
Green marketing has drawn the attention of academics and practitioners during the last few decades. However, no holistic framework has been developed on how to evaluate the implementation of green marketing orientation at the organization level. The article has an objective to analyze methodological perspective of evaluation of green marketing. Authors have identified that questionnaires, interviews, and observations are the most common methods chosen for the evaluation of green marketing performance. The evaluation of green marketing performance can be based on particular scales applicable for the evaluation of green marketing. This study enriches the literature by building a base for the formulation of benchmarks for the evaluation of green marketing performance in contemporary organization. Results of the research have shown that green marketing performance should be undertaken at strategic, tactical and operational levels.
\end{abstract}

Keywords: Green marketing, progress, methodological framework, criteria.

JEL Classification: M30, M31, M37, Q56.

\section{INTRODUCTION}

Customers all over the world are worried about sustainability-related issues more than ever before by clearly demonstrating the increasing interest in environment protection aiming to terminate or prevent global warming, socially irresponsible consumption, squandering of the ozone layer. Customers worldwide are increasingly concerned about issues relating to sustainability. This is clearly demonstrated through their ever increasing interest in the protection of the environment seeking to terminate or prevent further increases in, global warming, to prevent the over-consumption of non-renewable resources and to halt the depletion of the ozone layer. Customer attitudes have shifted significantly over the last decade from being very skeptical about green products to the commoditization of green products. In turn, many organizations have responded to this shift by embracing green initiatives. Products that are non-toxic, recyclable, and environmentally friendly have become the focus of marketers to satisfy customer demand and increase profits. Organizations in many industries worldwide are making changes to products and marketing, emphasizing green principles in response to customer demand and to improve the global environment. Organizations have to allocate additional investments for greening the marketing, so evaluation of performance of green marketing becomes a must.

The implementation of green marketing initiatives has been discussed in many different contexts (Rex \& Baumann, 2007; Chan, 2013; D'Souza et al., 2015; Saxena, 2015). However, there are few examples of methods that could be used to evaluate organization's level of and progress in green marketing. Therefore, to develop approaches to assess green marketing performance, intensive research is required. This study aims to investigate a methodological background for green marking evaluation.

Copyright (C) 2019. Ilona Skackauskiene, Neringa Vilkaite-Vaitone. Published by RTU Press

This is an Open Access article distributed under the terms of the Creative Commons Attribution License

(http://creativecommons.org/licenses/by/4.0/), which permits unrestricted use, distribution, and

reproduction in any medium, provided the original author and source are credited. 
The paper begins with a discussion of the problems that arrive when evaluating performance of green marketing. This is followed by a description of scales and methods proposed in previous research and a conclusion summarizing the insights the research provided.

\section{PROBLEMS IN THE MEASUREMENT OF GREEN MARKETING PERFORMANCE}

Previous green marketing research has focused on customer profile and the size of the market (Rex \& Baumann, 2007). This has meant that the information gathered is very much from the customer perspective and information regarding organization-level green marketing orientation and implementation is limited.

In addition to this, there are misconceptions around the term "green marketing." The concept of green marketing appeared at the end of 1960s (Zampese et al., 2016; Papadas et al., 2017). This concept is concerned with such terms as ozone friendly, recyclable, etc. However, in some analyses green marketing has been restricted to advertising only (Chen, 2016) while others include the evaluation of marketing strategies that have no bearing on "greenness" (Nadanyiova et al., 2015). These discrepancies of meaning lead to difficulties in the evaluation of green marketing performance.

We suggest that any assessment of green marketing processes should be based on a wide perspective of green marketing. Previous literature review in the field of green marketing has described green marketing of an organization as its undertaking of strategic, tactical and operational marketing activities with a holistic aim to make, market and deliver their products with the minimum environmental impact possible (Vilkaite-Vaitone, Skackauskiene, 2019). This broad notion needs an evaluation strategy that is based on a synthetic and integrated concept of green marketing, a concept confirmed by Z. Yong et al. (2011) who state that green marketing evaluation is synthetic includes multiple objects, elements and levels of processing.

As environmental issues become increasingly important to customers, competitors, governments and international organizations, some organizations may choose to appear greener by promoting themselves as green rather than being green. This practice is called "green washing". When large, international companies (i. e. Walmart, Starbucks, BP, etc.) are being accused of "green washing", it is essential that the choice of method applied for the evaluation of green market initiatives and the progress made reveals the real situation rather than one merely beneficial to the company.

Literature review results in the typology of approaches to green marketing: assertive and defensive. Organizations that follow an assertive approach to green marketing aim to respond to market trends and reach beyond stakeholder expectations. Defensive green marketing can be described as strategies that mean that organization only meets the minimum regulations, often to avoid penalization of financial or other type (Chan, 2013). The chosen method for the assessment of green marketing needs to reveal either the defensive or assertive marketing strategy of the organization in question.

The evaluation of green marketing and its success and progress should give a specific result that indicates the level of greenness of an organization. A numerical result is the most preferable. However, quantification of a scale for the performance of green marketing becomes a challenge in most cases (Yong et al., 2011). 
Green marketing researches have been limited to national boundaries (Rivera-Camino, 2007; Yadav et al., 2016; Duffett et al., 2018). There exists a possibility that a recommended method would not be appropriate for organizations operating in differing surroundings and contexts. Therefore, the evaluation method should allow for organizations operating at both national and international levels.

Past studies have generated both theoretical and practical insights into green marketing evaluation but have also highlighted problems experienced in the process of evaluation. It is essential that the chosen method can (1) reveal organization's advancement at strategic, tactical and operational levels, (2) show the factual state of performance of green marketing within an organization, (3) identify the type of strategy that is used, (4) reveal the level of green marketing performance in the organization, and (5) be applicable in case of international organizations.

\section{METHODOLOGICAL FRAMEWORK FOR THE EVALUATION OF GREEN MARKETING PERFORMANCE}

In undertaking a literature review, we found that the most common techniques used in the evaluation of green marketing were questionnaires, observations and interviews. Questionnaire researches (Rivera-Camino, 2007; Abzari et al., 2013; Chan, 2013; Ko et al., 2013; Richey et al., 2014; Majerova, 2015; Nadanyiova et al., 2015; Singh, Kumar, 2015; Yadav et al., 2016; Papadas et al., 2017), and observations (Ham, Lee, 2011) are common for the evaluation of green marketing. These evaluations are grounded on data collected from organizations or their customers. C. Gurau and A. Ranchhod (2005) conducted interviews with British and Romanian organizations in order to find out possibilities and difficulties faced in implementing green marketing at international level. by T. Paiva, V. Garcia (2016) and R. Duffett et al. (2018) also applied interview method in order to investigate green marketing in Portugal and South Africa respectively. Combined data multi-gathering techniques are also considered to be acceptable for the evaluation of green marketing performance (Fuentes, 2015; Saxena, 2015; Chen, 2016; Duffett et al., 2018). C. Fuentes (2015) applied a combination of observations, interviews, collection and analysis of artifacts in order to evaluate green marketing performance. R. Duffett et al. (2018) used a twopronged approach and employed in-depth interviews for an initial qualitative study followed by a quantitative questionnaire.

The review and analysis of the research in the field of green marketing has revealed a large variety of scales for the measurement of green marketing. Out of the ten measurement scales that were explored in this research (Chan, 2013; Fraj et al., 2013; Ko et al., 2013; Richey et al., 2014; D’Souza et al., 2015; Yadav et al., 2016; Papadas et al., 2017; Duffett et al., 2018; Chen, Yang, 2019; Dzulkarnain et al., 2019), three were one-dimensional tools for the measurement of green marketing performance (Fraj et al., 2013; Richey et al., 2014; Duffett et al., 2018). Scholars also proposed multidimensional tools to measure green marketing performance (Chan, 2013; Ko et al., 2013; D'Souza et al., 2015; Yadav et al., 2016; Papadas et al., 2017; Chen, Yang, 2019; Dzulkarnain et al., 2019). Multidimensionality in particular cases did not assure a systemic approach to green marketing concept. It is noticeable that the majority of the previous scales that were reviewed in this research did not consider green marketing at three distinct levels: strategic, tactical and operational.

A review of scales previously proposed revealed that much of the existing literature focuses on top management (Chan, 2013; Fraj et al., 2013; Richey et al., 2014; D'Souza et al., 2015; Papadas et al., 2017; Duffett et al., 2018; Chen, Yang, 2019; Dzulkarnain et al., 
2019). There exists an alternative to ground scales of green marketing on customers (Ko et al., 2013; Yadav et al., 2016).

An analysis of the existing literature regarding green marketing performance lets to formulate a conclusion that there exists a broad variety in the approaches of green marketing and in the methods and scales for green marketing evaluation. The shortage of a systemic approach to green marketing evaluation within organizations leads authors of this article suggesting a newly developed approach to the evaluation of green marketing performance.

\section{CONCLUSION}

This study has investigated the methodological backgrounds used for the evaluation of green marketing. This included a retailed literature review which revealed that the selection of suitable methods, criteria, and scales for the evaluation of green marketing performance is not straightforward and achieving a true evaluation of performance can be problematic.

Our findings suggest that questionnaires are predominantly used for the evaluation of green marketing. Significantly, this study implies that much of the previous research undertaken has had either a too constricted or too wide focus to gain an awareness of green marketing at strategic, tactical and operational levels. Particularly noticeable in the scales intended to measure green marketing performance is the lack of elements relating to operational marketing.

Future research may be able to concretize scales for the evaluation of green marketing progress by encompassing both academic and business experts. The next step in the research is to develop a scale that allows the measurement of green marketing at strategic, tactical, and operational levels.

\section{ACKNOWLEDGMENT}

This project has received funding from European Social Fund (project No 09.3.3-LMT-K-712-02-0116) under grant agreement with the Research Council of Lithuania (LMTLT).

\section{REFERENCES}

Abzari, M., Shad, F. S., Sharbiyani, A., Morad, A. P. (2013). Studying the effect of green marketing mix on market share increase. European Online Journal of Natural and Social Sciences, 2(3), 641-653.

Chan, E. S. W. (2013). Managing green marketing: Hong Kong hotel managers' perspective. International Journal of Hospitality Management, 34, 442-461.

Chen, H. C., Yang, C. H. (2019). Applying a multiple criteria decision-making approach to establishing green marketing audit criteria. Journal of Cleaner Production, 210, 256-265.

Chen, S. (2016). Selling the environment: green marketing discourse in China's automobile advertising. Discourse, Context and Media, 12, 11-19.

D‘Souza, C., Taghian, M., Sullivan-Mort, G., Gilmore, A. (2015). An evaluation of the role of green marketing and a firm's internal practices for environmental sustainability. Journal of Strategic Marketing, 23(7), 600 615 .

Duffett, R., Edu, T., Haydam, N., Negricea, I. C., Zaharia, R. (2018). A multi-dimensional approach of green marketing competitive advantage: a perspective of small medium and micro enterprises from Western Cape, South Africa. Sustainability, 10, 1-27.

Dzulkarnain, I. S., Ariqoh, T., Maulida, N. (2019). Green marketing strategy for local specialty agro-industry development to support creative agro-industry. IOP Conference Series: Earth and Environmental Science, 230, 1-8.

Fraj, E., Martinez, E., Matute, J. (2013). Green marketing in B2B organisations: an empirical analysis from the natural-resource-based view of the firm. Journal of Business \& Industrial Marketing, 28(5), 396-410. 


\section{RTU 60TH INTERNATIONAL SCIENTIFIC CONFERENCE ON ECONOMICS AND ENTREPRENEURSHIP SCEE'2019 PROCEEDINGS}

Fuentes, C. (2015). How green marketing works: practices, materialities, and images. Scandinavian Journal of Management, 31, 192-205.

Gurau, C., Ranchhod, A. (2005). International green marketing: a comparative study of British and Romanian firms. International Marketing Review, 22(5), 547-561.

Ham, S., Lee, S. (2011). US restaurant companies' green marketing via company websites: impact on financial performance. Tourism Economics, 17(5), 1055-1069.

Jain, S. K., Kaur, G. (2004). Green marketing: an attitudinal and behavioural analysis of Indian consumers. Global Business Review, 5(2), 187-205.

Ko, E., Hwang, Y. K., Kim, E. Y. (2013). Green marketing' functions in building corporate image in the retail setting. Journal of Business Research, 66, 1709-1715.

Majerova, J. (2015). Analysis of Slovak consumer's perception of the green marketing activities. Procedia Economics and Finance, 26, 553-560.

Nadanyiova, M., Kicova, E., Rypakova, M. (2015). Green marketing and its exploitation in Slovak companies. Procedia Economics and Finance, 26, 219-226.

Ottman, J. A. (2017). The New Rules of Green Marketing. Strategies, Tools and Inspiration for Sustainable Branding. New York: Routledge.

Paiva, T., Garcia, V. (2016). ECO2SEIA - low carbon green label products: a green marketing "study case". Holos, 32(8), 1-15.

Papadas, K. K., Avlonitis, G. J., Carrigan, M. (2017). Green marketing orientation: conceptualization, scale development and validation. Journal of Business Research, 80, 236-246.

Rex, E., Baumann, H. (2007). Beyond ecolabels: what green marketing can learn from conventional marketing. Journal of Cleaner Production, 15, 567-576.

Richey, R. G., Musgrove, C. F., Gilison, S. T., Gabler, C. B. (2014). The effects of environmental focus and program timing on green marketing performance and the moderating role of resource commitment. Industrial Marketing Management, 43, 1246-1257.

Rivera-Camino, J. (2007). Re-evaluating green marketing strategy: a stakeholder perspective. European Journal of Marketing, 41(11/12), 1328-1358.

Saxena, S. (2015). Are they really green: flipping the second side of green marketing coin - a critical analysis using selected cases? Amity Global Business Review, 10, 110-113.

Singh, B., Kumar, S. (2015). A study on current status of green marketing in North India. Pacific Business Review International, 7(11), 16-23.

Vilkaite-Vaitone, N., Skackauskiene, I. (2019). Green marketing orientation: evolution, conceptualization and potential benefits. Open Economics, 2, 53-62.

Yadav, R., Dokania, A. K., Pathak, G. S. (2016). The influence of green marketing functions in building corporate image. Evidences from hospitality industry in a developing nation. International Journal of Contemporary Hospitality Management, 28(10), 2178-2196.

Yong, Z., Ming, F., Mingxia, W. (2011). A research on evaluation of green marketing performance based on gray system. http://citeseerx.ist.psu.edu/viewdoc/download?doi=10.1.1.196.9351\&rep=rep1\&type=pdf

Zampese, E. R. S., Moori, R. G., Caldeira, A. (2016). Green marketing as a mediator between supply chain management and organizational performance. Revista de Administracao Mackenzie, 17(3), 183-211.

Zhang, L., Fu, J. (2017). Performance evaluation of the green marketing of circular economy based on the combination of expert evaluation of neural network. $3^{\text {rd }}$ Asian Pacific Conference on Energy, Environment and Sustainable Development, 56-62.

\section{AUTHORS' SHORT BIOGRAPHY}

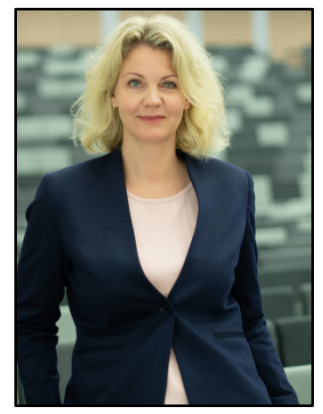

I. Skačkauskienè is Doctor of Social Sciences (2009), Professor, Head of Department of Management at Vilnius Gediminas Technical University (Lithuania). She has experience of over 15 years in research work and over 7 years in leading staff. Prepared two doctors of social (management) science; now, she is a research supervisor of 3 people maintaining a doctor's thesis of social (management) science. She has published over 50 publications during her scientific period and has read reports in Lithuanian and international conferences. Fields of scientific interest cover the creation process of new services, management of services, social and economic development, social innovation management, green organisation development.

Author's contact data: Sauletekio av. 11, LT-10223, Vilnius, Lithuania,

Ilona.skackauskiene@vgtu.lt; https://orcid.org/0000-0002-5078-3678 


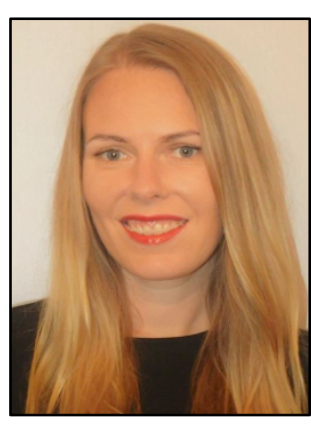

N. Vilkaite-Vaitone received Ph.D. degree at Vilnius Gediminas Technical University (Lithuania) in 2015. She is a Researcher at Management Department of the Faculty of Business Management at Vilnius Gediminas Technical University. N. Vilkaite-Vaitone is the author and co-author of more than 40 publications, 9 of them were publicized in journals indexed in Clarivate Analytics Web of Science database. Results of her researches had been presented in more than 20 conferences in Lithuania, Latvia, Poland, Slovenia, Bulgaria. Her research interests are: green marketing, customer loyalty, service business, socially responsible behaviour.

Author's contact data: Sauletekio av. 11, LT-10223, Vilnius, Lithuania, neringa.vilkaite-vaitone@vgtu.1t 